MARIA M. BOUŻYK

Wydział Nauk Pedagogicznych

Uniwersytet Kardynała Stefana Wyszyńskiego

Warszawa
Forum Pedagogiczne

$2017 / 2$

Wpłynęło: 10.04.2017

Zatwierdzono do druku: 12.05.2017

DOI: 10.21697/fp.2017.2.14

\title{
PATRIOTYZM W UJECIU JACKA WORONIECKIEGO: PODPOWIEDZI DLA WSPÓŁCZESNEJ PEDAGOGIKI
}

\begin{abstract}
Streszczenie: $\mathrm{W}$ artykule została podjęta kwestia patriotyzmu jako elementu w systemie wartości. Analizę oparto o przemyślenia filozoficzne Jacka Woronieckiego (1878-1949), pokazując, że mogą być nadal dobrym punktem odniesienia dla pedagogów w poszukiwaniach podstaw teoretycznych wychowania do patriotyzmu. Odkrycie istoty patriotyzmu może być pomocne przede wszystkim w rozpoznawaniu sensu działań wychowawczych w konfrontacji z ideami globalizmu czy z procesami integracyjnymi, które dokonują się w Europie. Za Woronieckim określa się patriotyzm jako sprawność moralną, należącą do jednej z czterech cnót kardynalnych, tj. do sprawiedliwości. Wskazuje się na jego mocne komponenty emocjonalne, a zarazem podkreśla, że, jak każda cnota, buduje się na wewnętrznej wolności człowieka, służąc zarazem jej ochronie. Zdolność przejawiania postaw patriotycznych świadczy o dojrzałości osobowej: człowiek odkrywając spoiwo relacji społecznych, jakim jest kultura, staje się gotowy do służby na rzecz ojczyzny.

Artykuł składa się z dwóch części. W pierwszej części zostanie przedstawiony problem wagi wychowania uczuć patriotycznych, w drugiej - kwestia miłości ojczyzny jako cnoty moralnej.
\end{abstract}

Słowa kluczowe: patriotyzm, uczucia patriotyczne, ojczyzna, cnota, moralność.

Celem artykułu jest zwrócenie uwagi na zagadnienie patriotyzmu, w kontekście optyki antropologicznej, charakterystycznej dla myśli Jacka Woronieckiego - pedagoga, duszpasterza, filozofa i teologa okresu międzywojnia ${ }^{1}$. Myśliciel, rozważając

1 Wśród licznych (szacowanych na ok. 100) prac (monografii i artykułów) poświęconych twórczości J. Woronieckiego znajdują się opracowania dotyczące patriotyzmu i kwestii z nim związanych, tj. narodu, państwa, nacjonalizmu. Wśród najnowszych publikacji można wymienić m.in. teksty następujących autorów: Dobrochny Bach-Goleckiej (2008), Jacka Grzybowskiego (2010, 2012; 2016); Katarzyny Kalinowskiej (2006), Ulricha Schradego (2000). Na uwagę zasługuje artykuł Bach-Goleckiej poświęcony wprost koncepcji patriotyzmu w ujęciu Woronieckiego oraz artykuł Grzybowskiego (2012), w którym koncepcje narodu, i ta sformułowana m.in. przez Woronieckiego, zostają skonfrontowane z ideologią globalizmu i jej skutkami społecznymi. Dodajmy, że bibliografię przedmiotową dotyczącą dorobku J. Woronieckiego (okres 
patriotyzm jako wartość moralną z perspektywy filozoficznej - wyjaśnijmy - warunkowanej metafizyką arystotelesowsko-tomistyczną, zostawił w swoich pismach również podpowiedzi o ładunku teoretycznym, który jak spróbujemy pokazać, nadal może inspirować pedagogów.

Na wstępie zaznaczmy, że Woroniecki dostrzega w patriotyzmie sprawność moralną, którą rozpatruje, zgodnie z tradycją klasycznej etyki, w kontekście sprawiedliwości, czyli jednej z czterech cnót kardynalnych (choć zauważa w niej także komponenty emocjonalne). Z historycznej perspektywy problematyka cnót kardynalnych jawi się jako najstarszy wykład pedagogiki. Ma u swych źródeł teoretyczny namysł nad bytem, a w szczególności - antropologię filozoficzną. Starożytni filozofowie szukali wytłumaczenia dla dostrzeganej na tle całej przyrody odmienności ludzkiego działania. W związku z tym w strukturze ludzkiego bytu wyróżnili dwie, właściwe tylko dla niej, duchowe siły: rozum i wolę. Jednocześnie, ze względu na niekwestionowalny rozwój człowieka, podkreślali niedokonany charakter tych sił. Ludzkie działanie, świadome i dobrowolne, podobnie jak cała sfera ludzkiego życia fizycznego, emocjonalnego, intelektualnego, musiało podlegać rozwojowi. Uzyskanie sprawności do samodzielnego postępowania klasycy uczynili więc głównym przedmiotem wychowania. Wszystkie sprawności moralne miały na względzie obiektywne dobro osoby i umiejętność pokierowania własnymi uczuciami. Dodajmy, że Woronieckiego interesował przede wszystkim wymiar praktyczny klasycznej filozofii - powiedzmy nawet mocniej: jej przełożenie na konkretne działania $\mathrm{w}$ procesie formacji moralnej człowieka. Zaangażowanie społeczne, $\mathrm{w}$ tym postawy obywatelskie, postrzegał on już jako następstwo tego procesu.

Nasze analizy zaczniemy od wyjaśnienia kwestii kształtowania uczuć patriotycznych, aby następnie skoncentrować się na problemie miłości ojczyzny jako cnoty moralnej.

\section{Uczucia patriotyczne}

W swojej etyce wychowawczej myśliciel wielokrotnie powoływał się na prace klasyków, np. Arystotelesa. Ponadto korzystał z przygotowanego przez Tomasza z Akwinu wyczerpującego opracowania problematyki sprawności (habitus operati$v u s$ ) i stałych usposobień (habitus entitativus) człowieka. Zaznaczmy, że Woroniecki starał się o przywrócenie kwestii sprawności dla namysłu pedagogicznego, bo - jak zauważał - pojęcie to, mimo jego eksplikatywności w sferze działań wychowawczych, popadło w zapomnienie wraz ze schyłkiem średniowiecza (Woroniecki 1986, t. 1, s. 333-337). Pomijano je w czasach nowożytnych, koncentrując się na kazuistyce, a w wieku XIX, pod wpływem materialistycznej psychologii - zastąpiono je pojęciem nawyku. Usprawnić w dziedzinie moralnej znaczyło tyle, co wyrobić

1916-200o) przedstawiła M. Filipiak (200o) w książce: Życie i myśl Jacka Woronieckiego OP. (red.) Gałkowski J., Niedziela M. L. Lublin: TN KUL, s. 277-297. 
przyzwyczajenie. Zatrzymajmy się na chwilę przy tej kwestii, bo jest ona istotna dla uchwycenia moralnego znaczenia patriotyzmu.

W postawach patriotycznych, jak i w innych postawach moralnych, mamy do czynienia z obecnością poruszeń zmysłowych, tj. emocji. Ten komponent odgrywa na tyle dużą istotną rolę w patriotyzmie, że nie tylko mówi się o uczuciach patriotycznych, ale wręcz definiuje się patriotyzm - szczególnie w literaturze anglosaskiej - jako uczucie (Heywood 2007, s. 176; 2008, s. 248-249). Tymczasem każda ze sprawności moralnych, a jest nią według Woronieckiego także patriotyzm, wyrasta z ducha wolności, w przeciwieństwie do nawyków. Nawyk ma charakter nieświadomy i działa automatycznie, sprawność natomiast jest świadoma. Mylące może być to, że zarówno nawyk, jak i sprawność powstają w konkretnych władzach ludzkiej duszy przez powtarzanie tych samych czynów. W konsekwencji prowadzą więc do utrwalenia skłonności: powstania w odnośnej władzy pewnej „ścieżki”. Woroniecki wyjaśnia ten proces: „Moment świadomego zastanowienia nieraz bywa sprowadzony do minimum, bo całą racją bytu sprawności jest oszczędzenie wysiłku i operowanie skapitalizowanym niejako doświadczeniem; ale tam, gdzie sprawność działa, zawsze jest to mgnienie interwencji rozumu, i ono to daje jej tę cechę umiaru czy też taktu, której brak nawykom działającym odruchowo bez udziału czynnika świadomości [wyróżnienia moje - M. B.]” (Woroniecki 1986, t. 1, s. 334).

Woroniecki zauważa, że w refleksji Tomasza z Akwinu kwestia nawyków - aczkolwiek dostrzeżona - nie jest traktowana jako część dziedziny życia moralnego w ścisłym sensie. W świetle dzisiejszej psychologii można powiedzieć, że nawyk jest odpowiednikiem „myśli automatycznej”, której obecność wywołuje emocje i tym samym oddziałuje na wolne działanie człowieka. Uchwycenie tych związków jest niezwykle pomocne w terapiach. Woroniecki, śledząc rozwój psychologii, uznawał tego typu zależności i doceniał znaczenie tej wiedzy dla lepszego poznawania ludzkiego działania, niemniej jednak podtrzymywał słuszność rozróżnień Tomasza. Argumentował, że filozofia sięga istoty moralności, której psychologia nie jest w stanie określić. Oddajmy głos autorowi: „Bardzo ważną różnicą między nawykiem a sprawnością jest to, że pierwszy opanowuje niemal całkowicie władzę, tak iż ona popełnia odruchowo zawsze te same czyny. Druga natomiast dając przewage pewnym czynom, pozostawia jednak władzy całkowitą swobodę spełniania innych czynów nawet wprost jej przeciwnych. Cnota równie jak i wada tylko skłania, ale nie zniewala, i człowiek zawsze zachowuje wolność postąpienia przeciw temu, do czego one skłaniają. Pierwiastek świadomości jest tu ostoją wolności" (Woroniecki 1986, t. 1, s. 334).

W związku z tym należy uznać, że sprawność moralna (cnota) nie przymusza, ale jest czymś, czym człowiek wychowany dysponuje i czego może użyć, ilekroć zechce. Nawyki łączą się ze sprawnościami, towarzyszą im, a nawet odgrywają pewną rolę w ich utrwalaniu, ale w ścisłym sensie nie wchodzą w zakres moralności (Woroniecki 1986, t. 1, s. 336). Jej pole wyznacza akt ludzkiej decyzji osadzonej na działaniu rozumu i woli. Zorientowanie wychowania na wewnętrzną wolność 
człowieka potwierdza także wypracowana przez Woronieckiego koncepcja charakteru (Woroniecki 1986, t. 1, s. 384). Ten filar ludzkiej tożsamości autor postrzega nie tyle jako sumę wad i cnót, co jako zdolność ustosunkowania się do nich. $\mathrm{Na}$ jakość charakteru (tzn. czy jest dobry, czy zły) wpływa decyzja o stosunku osoby do własnych wad. Ważne, aby zmierzać w kierunku osiągnięcia wewnętrznej harmonii (Woroniecki 1999, s. 268).

Omawiając zagadnienie różnicy między nawykiem a sprawnością warto jeszcze zwrócić uwagę na jej podstawy antropologiczne. Praktyczna filozofia Woronieckiego jest budowana na podstawie koncepcji człowieka jako bytu, który jest jednością psychofizyczną. W związku z tym ludzka potencjalność realizuje się zarówno w sferze materialnej, jak i duchowej, przyjmując formę ich dynamicznego współoddziaływania. Według autora, „potencjalność w sferze ducha jest o wiele głębsza i donioślejsza" niż materialna, a w dziedzinie moralnej jej realizacja wymaga wysiłku wychowawczego i autowychowawczego (Woroniecki 1999, s. 337). Niestety, jak zaznacza myśliciel, we współczesnej refleksji pedagogicznej ranga filozofii klasycznej znacznie zmalała - pedagog chętniej korzysta z wiedzy psychologicznej. Tymczasem w psychologii nastąpił zwrot ku materialistycznej antropologii, uniemożliwiający zasadne rozróżnianie nawyków i sprawności, w konsekwencji przyzwolono na traktowanie sprawności jako nawyków, a duchowości jako psychiczności.

Antropologia Woronieckiego odbiegała od obowiązujących w ówczesnej nauce tendencji naturalistycznych. Nasz pedagog widział je jako zagrożenie dla ludzkiej wolności. Jego spostrzeżenia zachowały po latach aktualność. W świetle ustaleń brytyjskiego politologa Andrew Heywooda (Heywood 2009, s. 30-32) w XX wieku teorie polityczne znalazły się pod rosnącym wpływem idei biologicznych i socjologicznych. W latach 70. modne stało się wyjaśnianie zachowań społecznych w kategoriach biologicznego oprogramowania łączonego $\mathrm{z}$ domniemanym zespołem cech dziedziczonych ewolucyjnie (np. R. Dawkins) lub jako korelatu środowiska społecznego o wysoce deterministycznej wykładni teoretycznej (inżynieria społeczna, np. B. F. Skinnera).

Mając na uwadze powyższe wyjaśnienia, należy pamiętać, że definiowanie przez Woronieckiego patriotyzmu jako sprawności wyrasta z antropologii innej niż materialistyczna, a sam patriotyzm ma przede wszystkim wymiar duchowy, aczkolwiek skorelowany z ludzką psychicznością. Nie bez znaczenia jest sfera uczuć. Świetnie określił ją Clive S. Lewis jako swego rodzaju miłość, którą można nazwać ukochaniem „tego, co moje” czy swego rodzaju zadomowieniem (Lewis 1993, s. 33-43; por. także Król 2004, s. 15-16). Pisarzowi chodziło o emocjonalny związek nie tylko $\mathrm{z}$ rodzinnym domem, ale i z tym, co jest $\mathrm{w}$ jego pobliżu, a co traktujemy jako nieodłączną część swojego bycia w świecie. Doświadczamy tego np. wobec osób z sąsiedztwa, znanych widoków i dźwięków, zapachów i smaków, wobec określonego stylu życia czy lokalnego dialektu. Wywołują je także, oddziałujące na wyobraźnię opowieści o dawnych dziejach. Możemy przyjąć, że jest to zmysłowa 
miłość do domu „poszerzonego” terytorialnie, kulturowo i pod względem czasu. Lewis rozumiał znaczenie tego uczucia dla kształtowania postaw prospołecznych, tj. wychodzenia poza krąg rodzinnego egoizmu. Niemniej jednak przestrzegał, że pozostawione samo sobie, bez kontekstu, może się stać przedmiotem ideologicznej manipulacji i przerodzić się - jak to określał - w „demona patriotyzmu”. Pod tym względem do niebezpiecznych ideologii zaliczał: nacjonalizm, imperializm, kolonializm. Właściwe pokierowanie uczuciami wymaga więc rozeznania obiektywnego dobra osobowego. Tę myśl spotykamy właśnie w etyce Woronieckiego: „Zadaniem przeto wychowania nie jest wyrobić wzrok i słuch lub wzbogacić wyobraźnię i pamięć, ale nauczyć panować nad nimi i związanymi z nimi podnietami, tak iżby nie one nami rządziły i popychały nas, gdzie zechcą, ale abyśmy je mieli całkowicie w ręku i mogli się nimi posługiwać do celów, wskazanych przez rozum" (Woroniecki 1986, t. 1, s. 345, 378).

W związku z tym uczucia patriotyczne, w ścisłym sensie, to uczucia poddane rozumowi i woli, zgodnie z rozpoznaniem tego wymiaru dobra osobowego, za które odpowiada cnota patriotyzmu. Dobrze o tym pamiętać dziś, gdy patriotyzm staje się wartością podejrzaną. Nie przesądzając o zasadności pojawiającej się w przestrzeni publicznej krytyki zachowań patriotycznych, należy przypomnieć, że klasyczna etyka nie łączy patriotyzmu $z$ emocjonalnymi odruchami i stereotypami myślenia, ale zawsze z wysiłkiem wypracowania wewnętrznej wolności. Każda cnota, w tym patriotyzm, pociąga za sobą moralną czujność wobec wszelkich zagrożeń uprzedmiotowienia człowieka. Taka czujność powinna się budzić, jeśli procesy globalizacyjne dehumanizują życie społeczne.

Oczywiście istotny jest komponent „zadomowienia”, wyrażający się choćby w formie relacji między członkami jakiejś społeczności. Proces kształtowania się narodów - zauważa Woroniecki - opiera się na istniejących w każdym z nich związkach pokrewieństwa, powstałych na skutek zawierania małżeństw między osobami mieszkającymi na jakimś określonym terytorium. Poczucie przynależności do wspólnoty zostaje spotęgowane obyczajowością, językiem, a czasem i wyznawaną religią. Cała sfera emocji, które towarzyszą tym relacjom, wymaga rozumnego pokierowania, służącego dobremu odczytaniu zobowiązań moralnych wobec ojczyzny (Woroniecki 1986, t. 2-2, s. 123-124).

\section{Miłość ojczyzny}

Obowiązek miłości, wyjaśnia Woroniecki w świetle zasad teorii miłości Tomasza z Akwinu, zaznaczając, że jest on większy, im ściślejszy jest naturalny związek osób. Najmocniejsze relacje łączą rodziców i dzieci, następnie - dalszą rodzinę, dalej - naród. Ten naturalny układ relacji wymaga - zdaniem Woronieckiego odniesienia do wartości większych niż dobro narodu oraz podjęcia interpretacji w świetle prawdy o godności każdego człowieka. W przeciwnym razie obowiązek miłości łatwo może stać się pożywką dla różnych ideologii ubóstwiających 
własny naród lub może prowadzić do kształtowania postaw szowinistycznych. W tym względzie filozofia może służyć pedagogice, choćby przez podstawowe prawdy o istocie ludzkiego bytu.

Trzeba także dodać, że oprócz wyjaśnień filozoficznych Woroniecki sięga do interpretacji teologicznej. Przykazanie miłości bliźniego w praktyce życia zobowiązuje do szacunku dla innych narodów i zakazu nienawiści kogokolwiek, a w sferze refleksji pedagogicznej jeszcze wyraźniej pokazuje skalę formacji człowieka i uzyskanej dzięki niej wewnętrznej wolności w stosunku do tego, co „moje”. Poszerzając ten obszar zagadnień, warto przytoczyć wypowiedź Jacka Salija na temat stosunku do wrogów ojczyzny, przedstawioną w ramach rozważań nad polskim patriotyzmem okresu zaborów. Myśl niepodległościowa - jak zaznacza badacz - przybrała wtedy rozmiary swego rodzaju teologii wyzwolenia. Miały na to wpływ m.in. interpretacje trudnego doświadczenia krzywdy oraz stosunku do zaborców - rozpatrywane właśnie w duchu miłości chrześcijańskiej. Polscy patrioci zdali sobie sprawę, że zemsta zawsze „odbiera stronie pokrzywdzonej jej niewinność, czyni ją kimś równie krwiożerczym jak krzywdziciel”, rzeczywista miłość nieprzyjaciół natomiast „utrwala przywiązanie do prawdy i własnej godności, chroni przed upodleniem i biernym pogodzeniem się z krzywdą, toteż raczej umacnia w dążeniach do sprawiedliwości” (Salij 2005, s. 66-67). Jacek Salij zauważa, że przekonanie o dopełnieniu idei narodu ideą chrześcijańskiego uniwersalizmu pozwalało Polakom dostrzec w rozbiorach nie tylko niezasłużoną krzywdę, ale przede wszystkim moralną klęskę całej Europy, która łatwo pogodziła się z naruszeniem zasad sprawiedliwości (Salij 2005, s. 71-72).

Kontynuując nasze rozważania, zaznaczmy, że wykształcenie cnoty patriotyzmu, a więc świadomego ukierunkowania uczuć związanych z dobrem, jakim jest ojczyzna, dokonuje się dzięki pracy wychowawczej. Oczywiście cały proces osobowej formacji w tej dziedzinie, a więc to, czy kształtuje się czyjeś cnoty, czy nawyki, jest w jakiejś mierze uzależniony od przyjętej przez pedagoga antropologii. Wysiłek wychowawczy (i autowychowawczy), ma prowadzić - zdaniem Woronieckiego - do usprawnienia wszystkich władz duchowych człowieka i nadawać jego życiu moralnemu jedność i jednolitość, czyli kształtować charakter (Woroniecki 1986, t. 1, s. 373-374) $)^{2}$ Na charakter składa się wiele sprawności moralnych, pozostających we wzajemnej relacji i urzeczywistniających się pozytywnie (cnoty) lub negatywnie (wady). Żadna z cnót (dotyczy to także patriotyzmu) nie może być rozpatrywana

2 Przykładem praktyki wychowawczej Woronieckiego, odnoszącej się do patriotyzmu, mogą być jego gawendy wygłaszane do polskich żołnierzy, a wydane w 1921 roku w zbiorze pt. Raport Niebieski. Przytoczmy jeden z fragmentów tej publikacji: „[...] miłość Ojczyzny powinna być po miłości najsilniejszą pobudką dla powstrzymania nas od wszelkiej nieuczciwości. I nie tylko o skarb państwa i o rzeczy państwowe tu chodzi, ale i o rodaków, którzy są też cząstkami Ojczyzny i to jeszcze cenniejszym nawet od martwych przedmiotów użytku. Kto krzywdzi brata, cywila czy wojskowego, ten krzywdzi w nim Ojczyznę [...]” (Woroniecki 2000, s. 60). 
w izolacji od pozostałych, jakkolwiek każda działa w obrębie określonego obszaru ludzkiego życia pożądawczego.

Woroniecki posługuje się typologią cnót wypracowaną przez Tomasza z Akwinu, która - za tradycją starożytną - wszystkie cnoty grupuje w cztery kardynalne: umiarkowanie, męstwo, roztropność i sprawiedliwość. W świetle tej klasyfikacji patriotyzm należy do kręgu cnoty sprawiedliwości, ale wymaga choćby elementarnej prawości moralnej. Jak nie ma sprawiedliwego działania bez męstwa, umiarkowania oraz roztropności, tak nie będzie postaw patriotycznych bez zdobycia sprawności w opanowaniu podstawowych popędów i bez kształtowania prawego sumienia. Prawdziwy patriotyzm wymaga pracy nad sobą, a tym samym przyczynia się do pogłębienia u człowieka świadomości własnej wartości jako osoby.

Specyfika cnoty sprawiedliwości, z którą patriotyzm łączy się przedmiotowo, polega na tym, że dotyczy dziedziny stosunków ludzkich. O ile pozostałe cnoty kardynalne: umiarkowanie, męstwo, roztropność mają za przedmiot to, co człowiek potrzebuje dla siebie, sprawiedliwość odnosi się do dziedziny jego zobowiązań wobec innych ludzi. Pod względem wychowawczym - zaznacza Woroniecki sprawiedliwość ma wpoić człowiekowi „czułość sumienia na cudze uprawnienia”, a więc kształtować w nim obowiązkowość (Woroniecki 1986, t. 2-2, s. 69, 74-75). Chodzi o stałą gotowość (usprawnianie) ludzkiej woli do liczenia się w postępowaniu $z$ uprawnieniami innych osób czy grup społecznych. Patriotyzm należy do centralnej części cnoty sprawiedliwości, tzw. iustitia legalis, która odnosi się do uprawnień społeczności względem jednostki, a tym samym odpowiada za uwrażliwienie naszej woli na obowiązki społeczne. Aby precyzyjniej oddać w języku polskim istotę iustitia legalis, jako swego rodzaju prawzoru sprawiedliwości, myśliciel proponuje tłumaczenie łacińskiego słowa legalis jako „współdzielcza”3. W tej formie sprawiedliwości wyraża się bowiem współdziałanie członków społeczności na rzecz dobra wspólnego i ukrywa się najdoskonalszy - zdaniem Woronieckiego wzór życia moralnego, „nad którym w życiu przyrodzonym nie ma nic wyższego, a w życiu nadprzyrodzonym tylko miłość chrześcijańska" (Woroniecki 1986, t. 2, s. 76). Specyfiką tej formy sprawiedliwości jest niewspółmierność naszych możliwości do czci, którą powinniśmy otoczyć takie byty, jak: Boga, rodziców, ojczyznę. Woroniecki wyjaśnia w ten sposób: „Ci, którzy są uprawnieni, aby się od nas tej czci spodziewać, winni być zadowoleni z tego, co im damy przy najlepszych chęciach, choć nie dorównuje to temu, czego są godni [wyróżnienia moje - M. B.]" (Woroniecki 1986, t. 2-2, s. 76-77). Ponadto dodaje: „ojczyźnie każdy jest winien tyle, na ile go tylko stać” (Woroniecki 1986, t. 2-2, s. 125).

Ze słów Woronieckiego wynika, że patriotyzmu nie można oszacować według jednej miary. Najważniejsze są wysiłek i staranie indywidualne, podejmowane przez każdego na jego własną miarę, na miarę konkretnej osoby będącej członkiem

3 Por. polskie tłumaczenie Summy teologicznej autorstwa F. W. Bednarskiego. Tłumacz posługuje się terminem sprawiedliwość ogólna lub społeczna. 
społeczności narodowej czy państwowej. W rozważaniach autora dostrzec można także ukryte tezy antropologiczne, które stanowią zasadnicze ramy filozoficzne kwestii patriotyzmu. Mianowicie frazy: „winni być zadowoleni” oraz „przy najlepszych chęciach” sugerują całkowitą dobrowolność realizowania postaw patriotycznych. Miłość do ojczyzny wymaga fundamentu wewnętrznej wolności człowieka. Cześć ma być bezinteresowna, niemniej jednak ma charakter jakieś powinności, wynikającej z rzeczywistej relacji warunkującej istnienie człowieka.

Metafizyczny fundament sformułowania „ci, którzy są uprawnieni”, to przede wszystkim prawda o przygodności ludzkiego bytu, wyrażająca zarówno ontyczną relację do Stwórcy, jak i określająca całe jego istnienie od narodzin do śmierci. Człowiek zawdzięcza swoje życie fizyczne i duchowe nie tylko rodzicom, ale i społeczności, w której się wychowuje. Odzwierciedlając tę prawdę, klasyczna etyka wiąże cnotę sprawiedliwości z cnotami pokrewnymi: religijnością i pietyzmem (Sth 2-2, 101, 1). Pierwsza $z$ nich usprawnia do oddawania czci Bogu, druga do czci należnej rodzicom, rodzinie i ojczyźnie. Tak więc pietyzm to hołd składany społeczności, w której się wyrosło i której zawdzięcza się ukształtowanie swego życia fizycznego i duchowego (Woroniecki 1986, t. 2, s. 124). Woroniecki łączy ten problem z koniecznością realizowania ludzkiej potencjalności ze względu na realne dobro. Dobrem tym są różne dobra przyrodnicze, kulturowe, a głównie inne osoby: „Bez ram obyczajowych, jakie daje większa społeczność, sama rodzina nie byłaby w stanie doprowadzić do zaawansowanego rozwoju umysłowego i moralnego człowieka, najwyżej zachowałaby go przy życiu i nauczyła zaspokajać jego najprymitywniejsze potrzeby fizyczne" (Woroniecki 1986, t. 2-2, s. 125).

Cześć należy się w szczególności osobom sprawującym w ojczyźnie ważne funkcje, a także obyczajom narodowym, przeszłości narodu, zabytkom języka ojczystego oraz symbolom narodowym (Woroniecki 1986, t. 2-2, s. 125-126) ${ }^{4}$. W tym miejscu warto poszerzyć rozważania Woronieckiego o refleksję Jana Pawła II, dotyczącą określenie ojczyzny jako dziedzictwa otrzymanego po przodkach, czyli zespołu dóbr materialnych i duchowych, wypracowanego przez ludzi na określonym terytorium i w określonym czasie historycznym (Jan Paweł II 2005, s. 65-70). Depozytariuszem i przekazicielem wartości jest naród: w relacjach społecznych człowiek rodzi się do życia osobowego. Przypomnijmy, że kształtowanie postaw patriotycznych papież powierzał m.in. środowiskom akademickim.

4 Jako przykład można wskazać na znaczenie języka ojczystego w rozwoju intelektualnym i moralnym człowieka. Woroniecki widzi braki kultury umysłowej narodu jako konsekwencję niedocenienia roli nauczania języka ojczystego w systemie edukacyjnym. Myśliciel zaznacza: „Myśl szuka wyrazu nie tylko żeby się uzewnętrznić, ale też, aby wewnętrznie przybrać jasną ściśle określoną postać: wyraz zaś wywołuje myśl, kieruje jej rozwojem, zmusza do refleksji, do pogłębienia treści” (Woroniecki 2008, s. 95) oraz „[...] on [język - wyjaśnienie autorki] wciąż się w nas rozwija i wzbogaca, a $\mathrm{z}$ nim razem rozwija się i wzbogaca nasz umysł, rosą nasze zasoby duchowe" (Woroniecki 2008). 
Trzeba podkreślić, że Woroniecki, pisząc o czci należnej ojczyźnie, posługuje się tym pojęciem w duchu tradycji tomistycznej. Cześć to służba, a nie tylko poważanie, szacunek (Sth 2-2, q. 103). Myśl o patriotyzmie jako służbie potwierdzają różne współczesne klasyfikacje tego pojęcia. W literaturze przedmiotu mówi się m.in. o patriotyzmie opartym na wartościach republikańskich bądź też odwołującym się do silnego państwa lub zorientowanym na modernizację w sferze gospodarki i cywilizacji (Hermann 2012, s. 73-94). Ponadto, w odniesieniu do polskiej historii, rozróżnia się patriotyzm demokracji szlacheckiej, patriotyzm romantyczny oraz patriotyzm interesu narodowego okresu międzywojnia (Walicki 2009, s. 343-397).

Przywołajmy w tym miejscu także wypowiedź Marcina Króla dotyczącą konieczności poszukiwania formuły polskiego patriotyzmu adekwatnej do współczesnej sytuacji społeczno-kulturowej, a zarazem znajdującego swój wyraz w służbie (Król 2004, s. 14-22,127-133). W kontekście konsumeryzmu towarzyszącego globalizmowi trafny wydaje się w szczególności postulat Jacka Salija, aby w pracy dla innych oraz społeczeństwa odnajdywać nie tylko korzyści materialne, ale właśnie wymiar służby (Salij 2005, s. 147-150). Należy więc stwierdzić, że w teorii wychowania patriotycznego, którego celem jest porzucanie postaw egoistycznych na rzecz bezinteresownej miłości ojczyzny, ważne jest odczytanie relacji ontycznej łączącej człowieka z ojczyzną, a więc rozpoznanie obiektywnego dobra, które ona stanowi w jego życiu.

Oceniając patriotyzm, pytając o jego aktualność, pamiętajmy, że jego zasadnicze ramy wyznacza cnota sprawiedliwości. Tomasz z Akwinu zwraca uwagę, że pietyzm odnosi się do ojczyzny jako do jednej z podstaw istnienia człowieka, a sprawiedliwość współdzielcza (społeczna) ma na względzie dobro ojczyzny jako dobro ogółu. Patriotyzm w tym zasadniczym wymiarze wyraża się - zdaniem Woronieckiego - w poszanowaniu praw własnej ojczyzny, pracy wzmagającej jej dobrobyt, sumiennym płaceniu podatków na jej utrzymanie czy świadczeń na jej korzyść, a nawet poświęceniu życia w jej obronie. Przykłady te są - zdaniem myśliciela - uszczegółowieniem cnoty sprawiedliwości współdzielczej (Woroniecki 1986, t. 2-2, s. 123). W związku z tym dojrzały patriotyzm powinien wyrażać się zdolnością przedkładania dobra ogółu nad dobro własne (Woroniecki 1986, t. 2, s. 95). Jego zaś zaprzeczeniem jest wszelka prywata. Woroniecki zauważa: „Miłość własna jako odśrodkowe dążenie do spełnienia wszystkich pragnień swego «ja» z uszczerbkiem dla dobra całości, której jest się częścią - oto źródło wszelkiej anarchii w społeczeństwie, to ona jest owym specyficznym złem, które przeciwstawia się sprawiedliwości współdzielczej [...]" (Woroniecki 1986, t. 2).

W świetle przytoczonych słów patriotyzm zawsze będzie wartością trudną do zaakceptowania przez wszelkie ideologie podważające wartość wspólnoty. Woroniecki dostrzegał tę zależność w indywidualizmie, liberalizmie i etatyzmie, które zakładają, że przeciętny obywatel powinien zajmować się swoimi sprawami, np. bogacić się, a kwestie publiczne powierzać rządowi, urzędnikom, korporacjom, samorządom terytorialnym (Woroniecki 1986, t. 2-2, s. 96). Wymienione 
ideologie kształtują w człowieku - zdaniem myśliciela - obojętność na dobro wspólne, tworząc dobry kamuflaż dla ludzkiego egoizmu, a więc są hamulcem rozwoju społecznego i indywidualnego. Inną siłę destrukcji - bo jawnie wymierzoną w dobro wspólne społeczeństwa - prezentują, jak twierdzi Woroniecki, ideologie anarchistyczne i nihilistyczne. Autor postrzega je jako niezdolne do budowania wspólnoty, a także upatruje w nich źródło chaosu w życiu społecznym (Woroniecki 1986, t. 2-2, s. 98-99).

Reasumując, wychowanie do patriotyzmu według Woronieckiego wymaga kształtowania w trzech obszarach: miłości psychicznej, służby i sprawiedliwości współdzielczej. Dlatego myśliciel ostatecznie określa patriotyzm jako zespół trzech cnót, dający ludzkiej duszy stały nastrój, na który składają się „[...] miłość do najbliższych, z którymi się wciąż obcuje, sprawiedliwość współdzielcza, skłaniająca do przenoszenia wspólnego dobra ojczyzny nad swoje własne, i wreszcie cześć dla tej społeczności, w której się wyrosło i od której przyjęło się obyczaje jako podstawę życia duchowego" (Woroniecki 1986, t. 2-2, s. 123).

Należy także podkreślić, że wypowiedzi Woronieckiego zawierają refleksje na temat ludzkiej przygodności, potencjalności oraz niepowtarzalności każdego człowieka: patriotyzm uobecnia się w indywidualnych postawach człowieka wobec ojczyzny, niesionych jego najlepszymi pragnieniami. Jednocześnie, stosownie do przyjętej antropologii, Woroniecki podkreśla możliwość rozwoju miłości w człowieku: przechodzenie od postaw egoistycznych do uznania wagi spraw wspólnych. Odbiciem tego procesu mogą być właśnie postawy patriotyczne. Patriotyzm, jak każda cnota, buduje się na wolności, właściwej tylko człowiekowi jako bytowi rozumnemu. Jednocześnie, jak każda cnota, służy ochronie tej wolności, przede wszystkim w wymiarze wewnętrznym. Etyka klasyczna nie rozróżnia bowiem odrębnych grup cnót: społecznych i indywidualnych. Wszystkie cnoty mają znaczenie społeczne i wszystkie mają wpływ na kulturę życia społecznego, np. politycznego. Patriotyzm nie może więc być oderwany od czyjejś prawości moralnej. Tak więc nie ma patrioty bez kształtowania charakteru. To, że ktoś dzięki swoim zdolnościom i wiedzy oddaje jakieś usługi dla ojczyzny, nie czyni go jeszcze patriotą. Językiem filozofii klasycznej można powiedzieć, że jako świetny fachowiec tworzy wartościowe dzieła. Tymczasem patriotyzm wchodzi w zakres dziedziny moralności, której przedmiotem jest coś innego niż jakość tworzonego dzieła, jest ona zorientowana na dobro człowieka jako osoby. Takie wyjaśnienie ma swoje uzasadnienie w filozofii klasycznej, na której Woroniecki opiera swój wywód dotyczący patriotyzmu: odróżniając mianowicie postępowanie moralne od szeroko rozumianej wytwórczości. W świetle tego rozróżnienia człowiek niemoralny może być wielkim twórcą, ale nigdy patriotą. Należy o tym przypominać, bo we współczesnym kanonie wartości akcent pada na wiedzę, wykształcenie, umiejętności praktyczne, kreatywność. Wszystkie one - jakkolwiek są czymś dobrym - wymagają jednak zintegrowania z życiem moralnym człowieka, a więc każdorazowego rozeznawania kontekstu moralnego w konkretnych sytuacjach poznawczych i twórczych. Zdobyte cnoty, 
w tym patriotyzm, usprawniają ten proces i tym samym wpływają na moralność społeczną, a więc stają się istotnym czynnikiem kształtowania społecznych relacji.

\section{Bibliografia}

Filipiak M. (200o). Bibliografia podmiotowa i przedmiotowa Jacka Woronieckiego OP. W: Gałkowski J., Niedziela M. L. (red.). Człowiek - moralność - wychowanie. Życie i myśl Jacka Woronieckiego OP. Lublin: TN KUL, s. 277-297.

Grzybowski J. (2012). Czy idee nacjonalistyczne zakwestionuja społeczeństwo liberalno-demokratyczne? Rozważania o przyszłości narodu w świecie diaspory i bezdomności. „Civitas: Studia z filozofii polityki”, nr 14, s. 137-163.

Grzybowski J. (2010). Filozoficzne skutki kontrkultury - profetyczne diagnozy o. Jacka Woronieckiego OP. „Universitas Gedanensis”, R. 22, t. 40, s. 17-36.

Hermann H. (2012). Jakiego patriotyzmu potrzebuja dziś: Polska i Polacy? W: Skrabacz A. (red.). Patriotyzm współczesnych Polaków. Warszawa: Dom Wydawniczy Elipsa.

Heywood A. (2007). Ideologie polityczne. Wprowadzenie, tłum. Habura M., Orłowska N., Stasik D., Żyro. T. (red. nauk.). Warszawa: Wydawnictwo Naukowe PWN. Heywood A. (2008). Klucz do politologii. Najważniejsze ideologie, systemy, postaci, tłum. Kornobis P., Wolański K. Warszawa: Wydawnictwo Naukowe PWN.

Heywood A. (2009). Teoria polityki. Wprowadzenie, tłum. Jasiński M., Maliszewska B., Stasiak D. Warszawa: Wydawnictwo Naukowe PWN.

Jan Paweł II (2005). Pamięć i tożsamość. Rozmowy na przełomie tysiacleci. Kraków: Wydawnictwo Znak.

Król M. (2004). Patriotyzm przyszłości. Warszawa: Wydawnictwo „Szklane Domy”. Lewis C.S. (1993). Cztery miłości, tłum. Wańkowicz M. Warszawa: IW PAX.

Salij J. (2005). Patriotyzm dzisiaj. Poznań: „W Drodze”.

Schrade U. (2000). Problematyka narodu i ojczyzny w ujęciu J. Woronieckiego i I. M. Bocheńskiego. „Arcana”, 33, nr 3, s. 6o-78.

Tomasz z Akwinu (2000). Skrót zarysu teologii (Summy teologicznej), tłum. Bednarski F. W. Warszawa: Wydawnictwo Antyk.

Walicki A. (2009). Kultura i myśl polska. Prace wybrane. T. 1: Naród, nacjonalizm, patriotyzm. Kraków: Universitas.

Woroniecki J. (1986). Katolicka etyka wychowawcza. Lublin: RW KUL.

Woroniecki J. (2002). Raport Niebieski. Lublin: FSViIEN.

Woroniecki J. (2008), Szkoła narodowa a nauczanie języka ojczystego. W: W szkole wychowania. Teksty wybrane. Lublin: FSV IEN, s. 87-108.

Woroniecki J. (1999). Wady moralne i stopnie ich nasilenia. „Człowiek w Kulturze”, nr 12, s. 265-270. 


\title{
PATRIOTISM ACCORDING TO JACEK WORONIECKI: SUGGESTIONS FOR MODERN PEDAGOGY
}

\begin{abstract}
The article deals with the issue of patriotism as a part of the system of values. The analysis is based on the philosophy of Jacek Woroniecki (1878-1949) and argues that his ideas can still be a good point of reference for educators in their search for the theoretical foundations of education for patriotism. The discovery of the essence of patriotism can be especially useful in diagnosing the sense of educational activities for patriotism confronted with the ideas of globalisation and the process of European integration. Woroniecki defined patriotism as a moral skill belonging to one of the four cardinal virtues, i.e. justice. He highlighted its strong emotional components and also emphasized that, like any virtue, patriotism is built on the inner freedom of man, and, at the same time, protects this freedom. The ability to manifest patriotism indicates personal maturity: while discovering culture, which binds social relations, man becomes ready to serve his country. The article consists of two parts. Part 1 presents the problem of the importance of education of patriotic feelings; Part 2 shows the love of the motherland as a moral virtue.
\end{abstract}

Keywords: patriotism, patriotic feelings, homeland, virtue, morality.

Maria M. Boużyk - doktor habilitowany nauk humanistycznych w zakresie filozofii, zatrudniona na Wydziale Nauk Pedagogicznych Uniwersytetu Kardynała Stefana Wyszyńskiego w Warszawie. W badaniach koncentruje się na problemach filozofii religii, antropologii filozoficznej i filozofii wychowania, a w szczególności na kwestii filozoficznego uzasadnienia otwarcia pedagogiki na wartości chrześcijańskie. Monografia autorska: Wychowanie otwarte na religie. Polska Szkoła Filozofii Klasycznej o roli religii w wychowaniu (Warszawa 2013).Adres e-mailowy: m.bouzyk@uksw.edu.pl. 